\title{
Quantitative Assessment of Environmental Sensitivity to Desertification in Sidi Abdel-Rahman Area, Northern West Coast of Egypt
}

\author{
A. M. Saleh, A. B. Belal and M. E. Jalhoum \\ Soil Sciences Dept., National Authority for Remote Sensing and Space Sciences \\ (NARSS), Cairo, Egypt
}

\begin{abstract}
7 HIS STUDY presents the assessment and mapping of the environmentally sensitive areas (ESA) to desertification in Sidi-Abdel Rahman area, Northern West Coast of Egypt using MEDALUS model. The desertification indices in Sidi-Abdel Rahman area were identified based on remote sensing data, Geographic information Systems (GIS), and field survey data. These indices were soil quality index, climate quality index, vegetation quality index, erosion quality index, land management quality index, and social quality index. The results of the current study for sensitivity to desertification showed that $20.62 \%$ of the whole region $(8510$ ha) is medium-fragile sensitive to desertification, $43.36 \%$ (17893 ha) is high-fragile sensitive to desertification, $35.35 \%$ (14586 ha) is low-critical sensitive to desertification, and $0.66 \%$ (274 ha) is medium-critical to desertification. In general, the total area is classified as fragile (F3) and thus insensibly susceptible to desertification. Sidi-Abdel Rahman area is sensitive to desertification owing to low vegetation cover, soil quality, mismanagement, climate condition, wind, and water erosion.
\end{abstract}

Keywords: Desertification, MEDALUS model, Indicators, Assessment, Mapping, Sidi AbdelRahman, Egypt

\section{Introduction}

Desertification is a global phenomenon which affects about one billion populations in about one hundred countries (Adger et al., 2000). The interference and interaction between the various factors such as climate, land cover, change in land use and natural and physical human activities resulted in the increase of desertification phenomenon (Thomas, 1997 nd UNCCD, 2000). The human factor is considered as the most important dynamic mechanism that affects increasing the desertification phenomenon (Herrmann and Hutchinson, 2005). Susceptibility to desertification is depending on the context (UNEP, 1992, Rubio, 1995 and Thornes, 1995) and any small change over specific threshold will affect the equilibrium between the other desertification factors and leads to undesired irreversible changes in desertification status (Tucker et al. 1991, Nicholson et al. 1998 and Montanarella, 2007). In the Mediterranean region the climate conditions, high erodible lands, low and decreased vegetation cover, and low organic materials are the most important causes for the increase of what is called the environmentally sensitive areas (ESA) (Ferrara et al., 1999 and Zambon et al., 2017). The Susceptibility to desertification were evaluated and assessed by different methods and models such as direct observations, mathematical models, parametric equations, and remote sensing techniques been developed (FAO/UNEP, 1984 and Turkmenistan Academy of Science (Babaev 1985).

MEDALUS methodology was developed by Kosmas et al. (1999) for identifying the regions sensitive to desertification appropriately at different scales and for the small changes in desertification factors (Luca and Sofia, 2011). MEDALUS model consists of four types of environmentally sensitive areas (ESA) to desertification phenomena which are, soil quality, climate quality, vegetation quality, and management quality. Many studies monitored and evaluated ESA in the Mediterranean region by MEDALUS model with accurate acceptable results (Basso et al., 2000, Collado et al., 2002, Kosmas et al., 2003, Runnstrom, 2003, Brandt, 2005, Yang et al., 2005, Jabbar and Chen, 2006, Gad and Lotfy, 2006, Sepehr et al., 2007, Ali and El Baroudy, 2008, Gad and Lotfy, 2008, Lavado et al., 2009, Bouabid et al., 2010, Gad and Shalaby, 
2010, Honardoust et al., 2011, Mohamed, 2013, Coscarelli et al., 2016, Lahlaoiet al., 2017 and Prăvălie et al., 2017). The objectives of this work are to use spatial analyses and Geographic Information System (GIS) for assessing and mapping the environmentally sensitive areas (ESAs) to desertification in Sidi Abdel-Rahman area, North West Coast of Egypt through the MEDALUS multi-factor approach based on both a general and a local knowledge of the environmental processes acting.

\section{Material and Methods}

The study area

Sidi-Abdel Rahman area is located at the north-western part of the coastal zone in the
Western Desert of Egypt (Fig. 1). It extends from westwards El Alamein to near El-Dabaa area. This area is bounded longitudes $28^{\circ} 30^{\prime} \mathrm{E} \& 29^{\circ}$ $00^{\prime} \mathrm{E}$ and Latitudes $30^{\circ} 45^{\prime} \mathrm{N} \& 31^{\circ} 05^{\prime} \mathrm{N}$, with an area of $412.63 \mathrm{Km}^{2}$. This region geologically consists of sedimentary formations belonging to the Tertiary and Quaternary period, (Said, 1990). Soil moisture regime is classified as aridic regime (torric), except for the soils that have high water table, where soil moisture regime could be an aquic condition. The soil thermal regime was identified as Thermic. On the basis of the key to soil taxonomy (USDA 2010), the soils of SidiAbdel Rahman area could be classified in the two categories of entisols and aridisols.

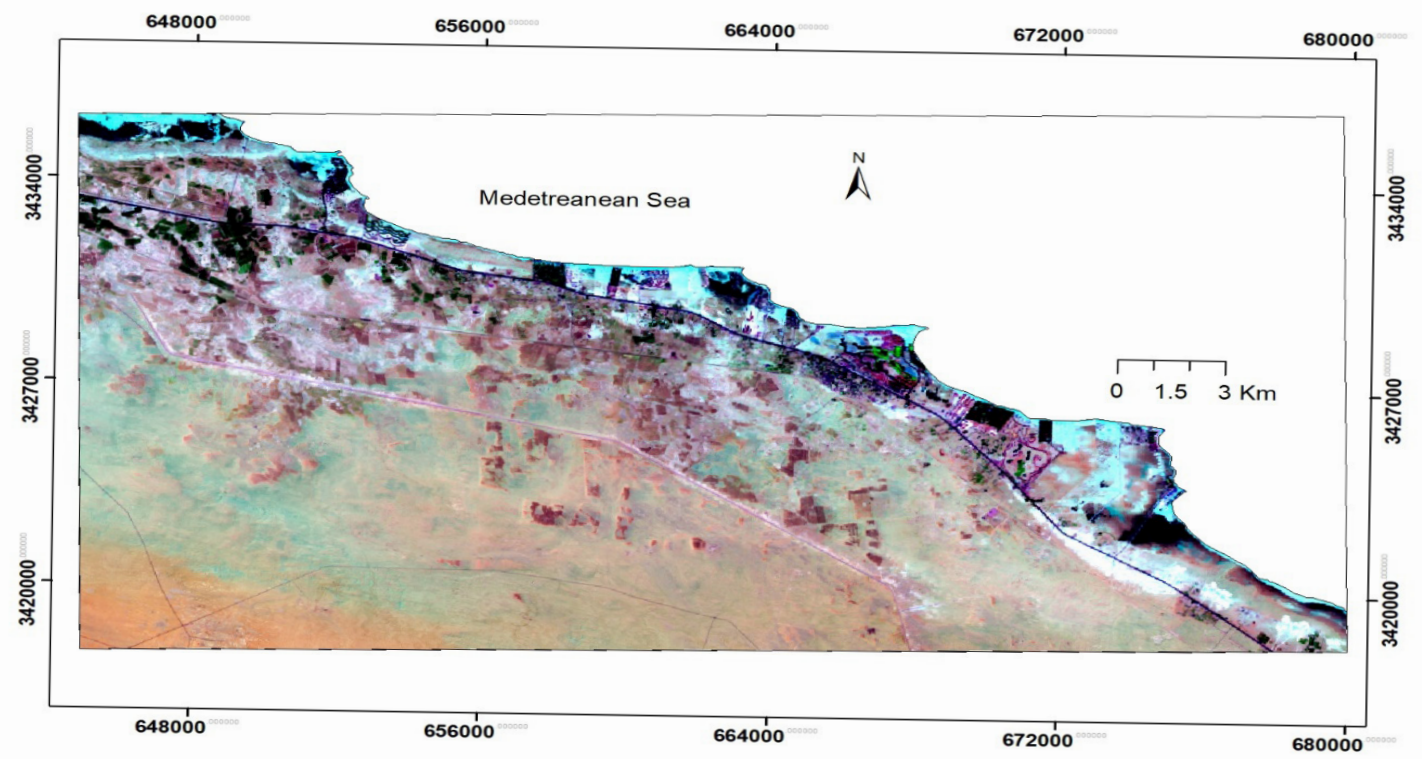

Fig. 1. Sidi Abdel-Rahman area location

\section{Methodology}

The proposed MEDALUS model by Kosmas et al. (1999) was used for computing the ESA index to determine the tendency to desertification in Sidi-Abdel Rahman area. Seventy - two target sites were sampled. The proposed MEDALUS model by Kosmas et al. (1999) was used for computing the ESA index to determine the tendency to desertification in Sidi-Abdel Rahman area. Seventy - two target sites were sampled (Fig. 2) according to the manual for describing land degradation indicators (Kosmas et al., 1999). The climate indicator was calculated based on annual rainfall (R); aridity index (A); evapotranspiration $(\mathrm{ET})$; slope aspect $(\mathrm{Sa})$ and erosivity (Ero). The climate parameters play a significant role in desertification (Reynolds \& Stafford Smith, 2002, Archer, 2004, Wang et al., 2005 and Zheng et al., 2006). Those parameters affect water availability for plants and might result in the inhibition of plant growth (Bahreini \& Pahlavanravi, 2013 and Thornes, 1995). The different classes of all the indicator parameters are shown in Table 1. The aridity factor was computed with sing the Goessen-Bagnolousmethod (AUA, 2008, Bahreini \& Pahlavanravi, 2013 and Parvari et al., 2011). The evapotranspiration (ET) was estimated with Turc method (Calanca et al., 2011 and Tavares et al., 2015). The rainfall factor was calculated with fournier index (FI). The slope 
aspect was derived from ASTERDEM satellite image. THe slope aspect was calculated using the aspect function of ArcMap 10.2.2 (ESRI, 2013). The climate quality index (CQI) was acquired by combining the revealed parameters using the following formula: $\mathrm{CQI}=(\mathrm{R} * \mathrm{~A} * \mathrm{Sa} * \mathrm{ET} *$ ERo) $)^{1 / 5}$

The soil indicator was calculated based on soil texture (St), parent material $(\mathrm{Pm})$, exposure rock outcrop (Rf), slope gradient $(\mathrm{Sg})$, soil depth (Sd), soil drainage condition $(\mathrm{Sr})$, soil electric conductivity (Se), soil carbonates content (Sc), soil gypsum (Sy) content and soil organic matter content (So). Calcium and gypsum contents were used in the soil quality index of Sidi-Abdel Rahman area as followed by (Le Bissonnais, 1996 and Mohamed, 2013). The Soil Quality Index (SQI) was calculated using the following equation: $\mathrm{SQI}=(\mathrm{St} * \mathrm{Rf} * \mathrm{Sg} * \mathrm{Sd} * \mathrm{Sr} * \mathrm{Se} * \mathrm{Sc}$ * Sy $*$ So) ${ }^{1 / 8}$

The vegetation indicator was assessed based on four parameters: plant cover density, drought resistance (Dr), and erosion protection (Ep) (Table 1). The thePlant cover (Pc) was computed by deriving the Normalized Difference Vegetation Index (NDVI) from Landsat satellite image of the study area. The Vegetation Quality index (VQi) was estimated using the following equation: $\mathrm{VQI}=(\mathrm{Pc} * \mathrm{Ep} * \mathrm{Dr})^{1 / 3}$

The erosion quality indicator was assessed based on water erosion (Wt), and wind erosion (Wi)paremeters (Table 1). The erosion indicator $(\mathrm{EQI})$ was calculated as: $\mathrm{EQI}=(\mathrm{Wt} * \mathrm{Wi})^{1 / 2}$

The management indicator was calculated based on land use $(\mathrm{Lu})$, policy and management $(\mathrm{Pm})$, Grazing intensity (Gi), soil and water conservation measures (Wc) and soil erosion conservation measures (Ec) (Table 1). The Management Quality index (MQI) was estimated using the following equation: $\mathrm{MQI}=(\mathrm{Lu} * \mathrm{Pm} *$ $\mathrm{Gi} * \mathrm{Wc} * \mathrm{Ec})^{1 / 5}$

The social indicator was calculated based on two parameters, the first parameter is the population density $(\mathrm{Pd})$ and the second parameter is the old age index (Oa) which is the percentage of the populationolder for more than 65 years (Tavares, 2015). The social indicator was determined using the following equation:

$$
\mathrm{SoQI}=(\mathrm{Pd} * \mathrm{Oa})^{1 / 2}
$$

Finally, the ESA index was calculated from the six quality indicators using the following quation: $\mathrm{ESA}=(\mathrm{SQI} * \mathrm{CQI} * \mathrm{VQI} * \mathrm{MQI} * \mathrm{EQI} * *$ SoQI $)^{1 / n}$

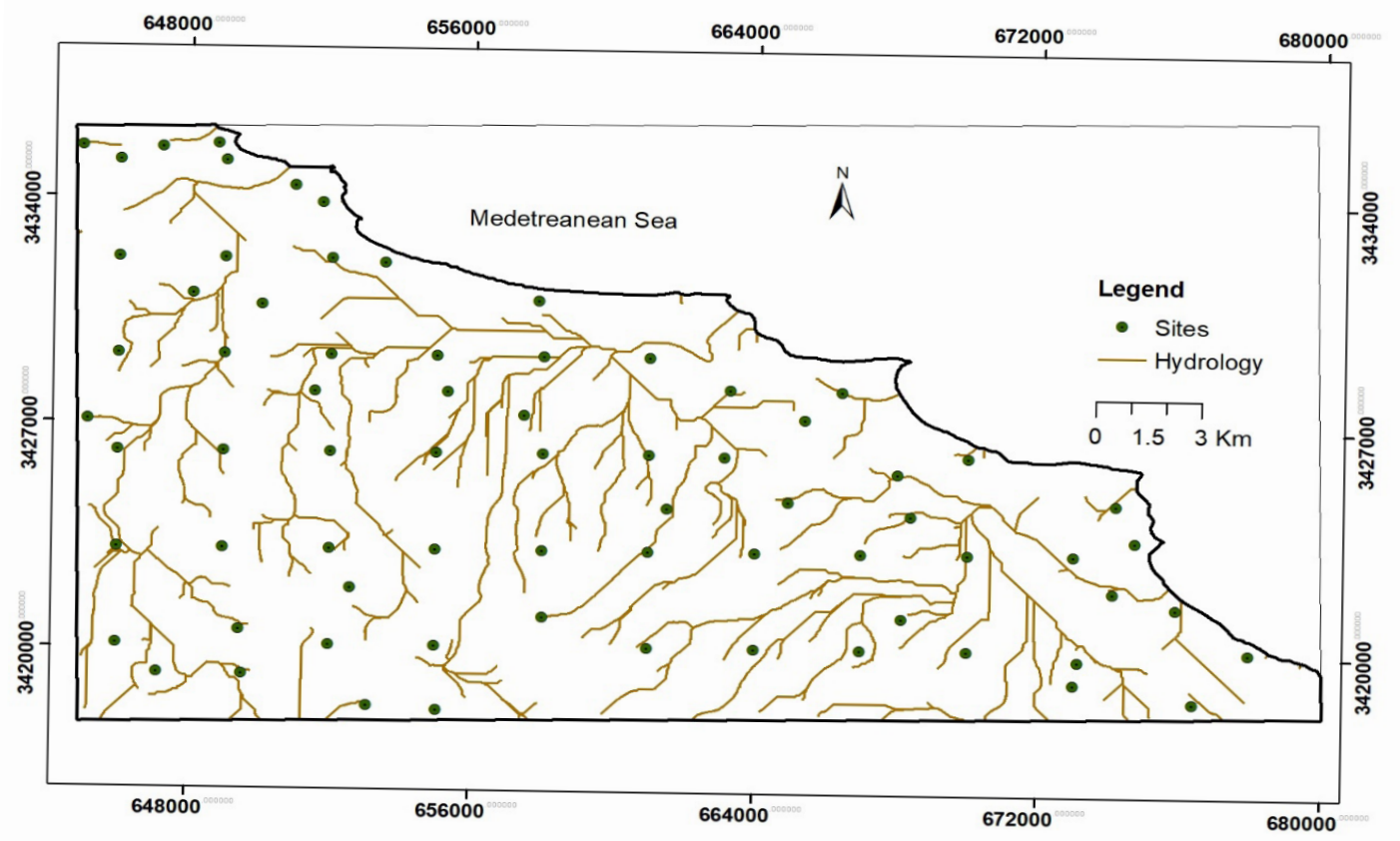

Fig. 2. The soil sampling locations in Sidi Abdel-Rahman area 
Table 1: The indices and its parameters and weights in Sidi Abdel-Rahman area

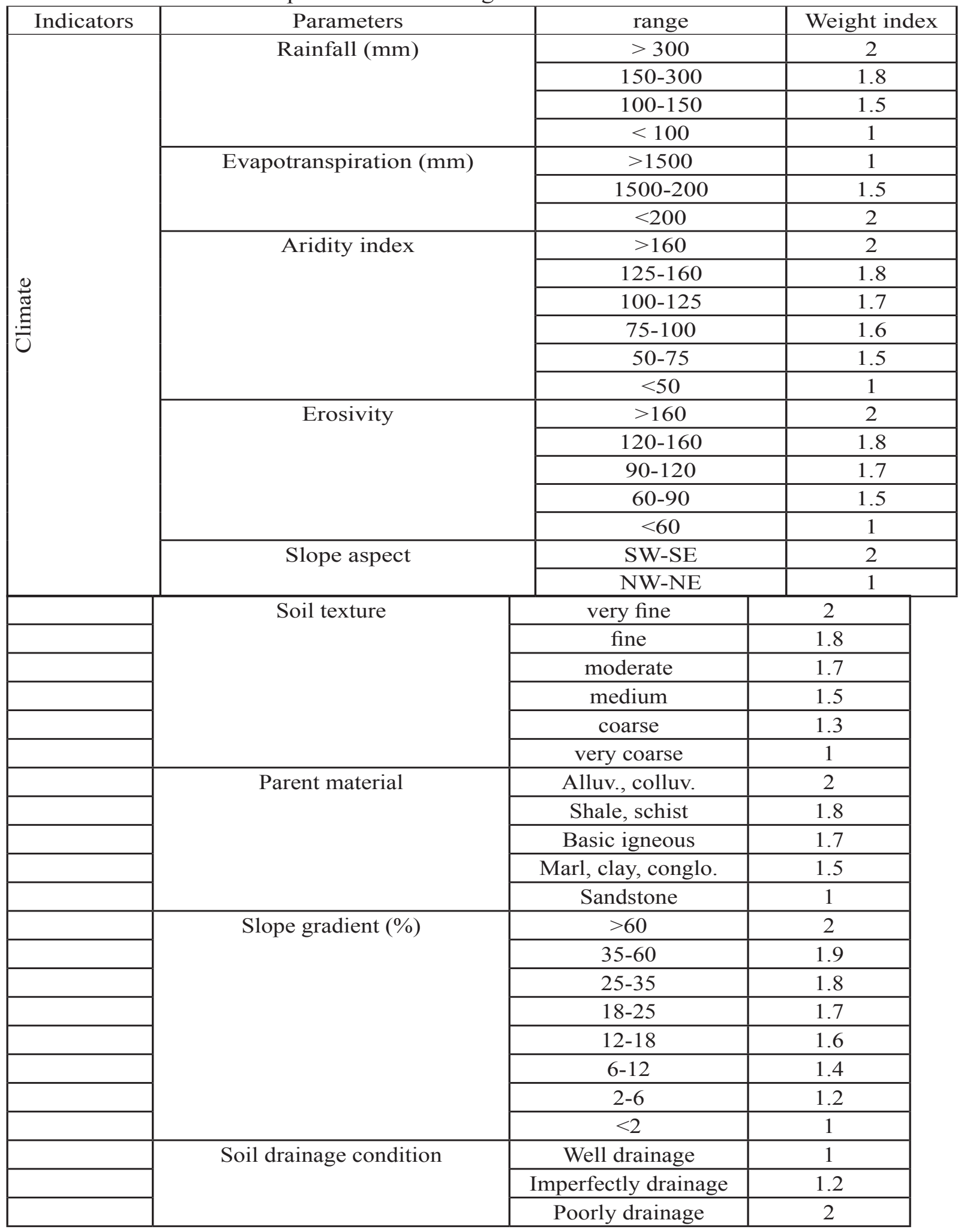


TABLE 1. Cont.

\begin{tabular}{|c|c|c|c|}
\hline Indicators & Parameters & range & Weight index \\
\hline & \multirow[t]{5}{*}{ Rock fragments } & $>60$ & 2 \\
\hline & & $30-60$ & 1.8 \\
\hline & & $10-30$ & 1.7 \\
\hline & & $<10$ & 1.5 \\
\hline & & none & 1 \\
\hline & \multirow[t]{5}{*}{ Electrical Conductivity (dS/m) } & $<4$ & 1 \\
\hline & & $4-8$ & 1.4 \\
\hline & & $8-16$ & 1.6 \\
\hline & & $16-32$ & 1.9 \\
\hline & & $>32$ & 2 \\
\hline & \multirow[t]{4}{*}{ Calcium carbonate content (\%) } & $<5$ & 1 \\
\hline & & $5-10$ & 1.2 \\
\hline & & $10-20$ & 1.5 \\
\hline & & $>20$ & 2 \\
\hline & \multirow[t]{4}{*}{ Gypsum content $(\%)$} & $<5$ & 1 \\
\hline & & $5-15$ & 1.2 \\
\hline & & $15-60$ & 1.5 \\
\hline & & $>60$ & 2 \\
\hline \multirow{11}{*}{ 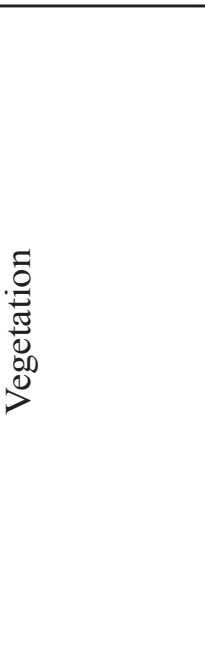 } & \multirow[t]{4}{*}{ Plant cover (NDVI) } & $>0.95$ & 1 \\
\hline & & $0.95-0.65$ & 1.2 \\
\hline & & $0.65-0.35$ & 1.5 \\
\hline & & $<0.35$ & 2 \\
\hline & \multirow[t]{3}{*}{ Drought resistance } & $\begin{array}{l}\text { Gardens, orchards, } \\
\text { rangelands }\end{array}$ & 1 \\
\hline & & $\begin{array}{l}\text { Permanent grassland, } \\
\text { annual crops and } \\
\text { grasslands }\end{array}$ & 1.5 \\
\hline & & Bare land & 2 \\
\hline & \multirow[t]{4}{*}{ Erosion protection } & High & 1 \\
\hline & & Moderate & 1.3 \\
\hline & & Low & 1.6 \\
\hline & & Very low & 2 \\
\hline \multirow{10}{*}{ 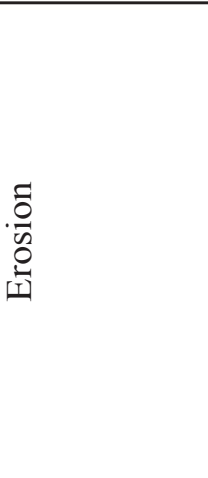 } & \multirow[t]{5}{*}{ Wind erosion } & Very low & 1 \\
\hline & & Low & 1.2 \\
\hline & & Moderate & 1.5 \\
\hline & & High & 1.7 \\
\hline & & Very high & 2 \\
\hline & \multirow[t]{5}{*}{ Water erosion } & Very low & 1 \\
\hline & & Low & 1.2 \\
\hline & & Moderate & 1.5 \\
\hline & & High & 1.7 \\
\hline & & Very high & 2 \\
\hline
\end{tabular}


TABLE 1. Cont.

\begin{tabular}{|c|c|c|c|}
\hline Indicators & Parameters & range & Weight index \\
\hline & & Very high & 2 \\
\hline \multirow{19}{*}{ 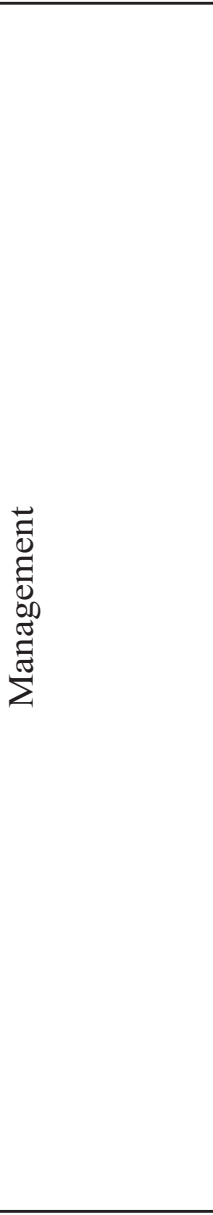 } & \multirow[t]{4}{*}{ Land use } & Agricultural lands & 1 \\
\hline & & Rangelands & 1.3 \\
\hline & & Poor and degraded & 1.6 \\
\hline & & Bare lands & 2 \\
\hline & \multirow[t]{3}{*}{ Grazing intensity } & Low & 1 \\
\hline & & Moderate & 1.5 \\
\hline & & High & 2 \\
\hline & \multirow[t]{4}{*}{ Policy and management } & No protected (b5\%) & 2 \\
\hline & & $\begin{array}{c}\text { Low protected (5- } \\
25 \%)\end{array}$ & 1.5 \\
\hline & & $\begin{array}{l}\text { Moderate protected } \\
(25-75 \%) \\
\end{array}$ & 1.4 \\
\hline & & $\begin{array}{c}\text { Adequate prot. } \\
(\mathrm{N} 75 \%)\end{array}$ & 1 \\
\hline & \multirow{4}{*}{$\begin{array}{c}\text { Soil and water conservation } \\
\text { measures }\end{array}$} & No measure & 2 \\
\hline & & $\begin{array}{l}\text { Inducing vapor } \\
\text { adsorption }\end{array}$ & 1.5 \\
\hline & & $\begin{array}{c}\text { Temporary storage of } \\
\text { water runoff }\end{array}$ & 1.4 \\
\hline & & Mulching & 1 \\
\hline & \multirow[t]{4}{*}{ Soil erosion conservation measures } & No protected $(<5 \%)$ & 2 \\
\hline & & $\begin{array}{c}\text { Low protected (5- } \\
25 \%) \\
\end{array}$ & 1.5 \\
\hline & & $\begin{array}{l}\text { Moderate protected } \\
(25-75 \%) \\
\end{array}$ & 1.4 \\
\hline & & $\begin{array}{c}\text { Adequate protected } \\
(\mathrm{N} 75 \%)\end{array}$ & 1 \\
\hline \multirow{8}{*}{$\cdot \frac{\pi}{0}$} & \multirow[t]{4}{*}{ Old age index (Oa) } & $>20$ & 2 \\
\hline & & $10-20$ & 1.5 \\
\hline & & $5-10$ & 1.4 \\
\hline & & $<5$ & 1 \\
\hline & \multirow[t]{4}{*}{ Population density $(\mathrm{Pd})$} & $>300$ & 2 \\
\hline & & $100-300$ & 1.5 \\
\hline & & $50-100$ & 1.4 \\
\hline & & $<50$ & 1 \\
\hline
\end{tabular}

According to the value of the ESA index, Sidi-Abdel Rahman area is classified into three categories as critical, fragile, and potential. The quality indicator and the ESA index were mapped using Inverse Distance Weighting (IDW) interpolation method in ArcGIS 10.2.2 software.

\section{Results and Discussion}

Based on the analysis of the mentioned indicators in the methodology, Sidi AbdelRahman southern parts in addition to some parts on the coast area are ranked as lowcritical to medium-critical environmental quality. The most critical indicators in Sidi Abdel-Rahman area are vegetation, and climate parameters. These indicators present a low to a very low environmental sensitive quality to desertification in about $69 \%$ of the Sidi Abdel-Rahman area while soil, management, erosion and social indicators showed values of $6.61 \%, 3.56 \%$ and $3.03 \%$, and $2.11 \%$, respectively in the low to very 
low environmental quality areas of Sidi Abdel-Rahman area. The results indicated that about $28.26 \%$ of Sidi Abdel-Rahman total area are characterized by very low climatic index located at the south parts (Fig. 3) while the northern parts of Sidi Abdel-Rahman area are characterized by very high quality which represent $60.74 \%$ of the total area owed to the amount of rainfall which reached to $150 \mathrm{~mm} /$ year in average.

The high soil quality index occupies about $59 \%$ of Sidi Abdel-Rahman total area represented in the middle and western parts of the area (Fig. 4). About $6.61 \%$ of Sidi Abdel-Rahman area is characterized by very low to low soil quality index located at the eastern and north-western parts of Sidi Abdel-Rahman area. The limiting factors of soil quality in Sidi Abdel-Rahman northern parts are salinization and daring condition as well as calcium carbonate content. The obtained results revealed that the areas characterized by a high vegetation quality occupied about $34 \%$ of the total area located in the middle and western parts of Sidi Abdel-Rahman area (Fig. 5) while an area about $36.1 \%$ of the total area are considered as very low and low vegetation quality located at the eastern, southern, and northsouthern parts of the investigated area. This lowness of vegetation cover existence in Sidi Abdel-Rahman area severely increases the erosion rates in the area.

The moderate erosion quality index occupied about $65 \%$ of Sidi Abdel-Rahman area (Fig. 6) while the area characterized by high quality represents about $29 \%$ of the whole area which is associated with cultivation.About $43 \%$ and $33.66 \%$ of Sidi Abdel-Rahman total area are characterized by moderate and high management quality (Fig. 7). The continuous soil cultivation by the local bedwin farmers is protecting the area from overgrazing. Also, the bedwins building barriers to conserve the rainfall water in local cisterns for use in irrigation in an appropriate land use system. The high social quality index dominating the area with 91.5\% of Sidi Abdel-Rahman area (Fig. 8) while the very low and low quality occupies about only $2 \%$ of the area.

The resulted distribution of desertification sensitivity (ESA) (Fig. 9 and 10) shows that the high-fragile (F3) ESA is located at the eastern through the middle and northwestern parts of Sidi Abdel-Rahman area and represents $43.36 \%$ of the total area (Table 2). The low-critical (C1) ESA is located in the south parts and represent $35.35 \%$ of the area while the medium-fragile (F2) ESA located at the western parts and represent $20.62 \%$ of the area. The medium critical (C2) ESA is very small in area about $0.66 \%$. The parts with high sensitivity to desertification is where the vegetation quality is poor. Similar results were observed in a study by Gad and Shalaby (2010) in Sinai and wadis in Eastern Desert of Egypt.

This study shows that the fragile EAS class is the dominant class in Sidi AbdelRahman area and plays a critical role in the desertification process. The high affected areas by desertification will be prone to remove the existing vegetative cover and increase the erosion rates as to any change in the current land use and also the change of climatic conditions.

\section{Conclusion}

The MEDALUS model is very valuable method in assessing the desertification phenomena in arid and semi-arid regions. In this study, The MEDALUS method was modified to develop a regional model in which desertification parameters were collected in Sidi Abdel-Rahman area using GIS. The combination of six quality indices each comprising several sub-indicators was analysed. Calcium carbonate content and gypsum content were input in soil quality index calculation as they are essential factors under Egyptian conditions for desertification sensitivity. The results showed that $20.62 \%$ of Sidi Abdel-Rahman area is mediumfragile ESA, $43.36 \%$ is high-fragile ESA, $35.35 \%$ is low-critical ESA, and $0.66 \%$ is medium critical ESA. This MEDALUS model allows to monitor desertification phenomena by taking the needed actions in the identified sensitive areas. The resulted ESA map is a good source of information to help Egypt. J. Soil Sci., 58, No. 1 (2018) 


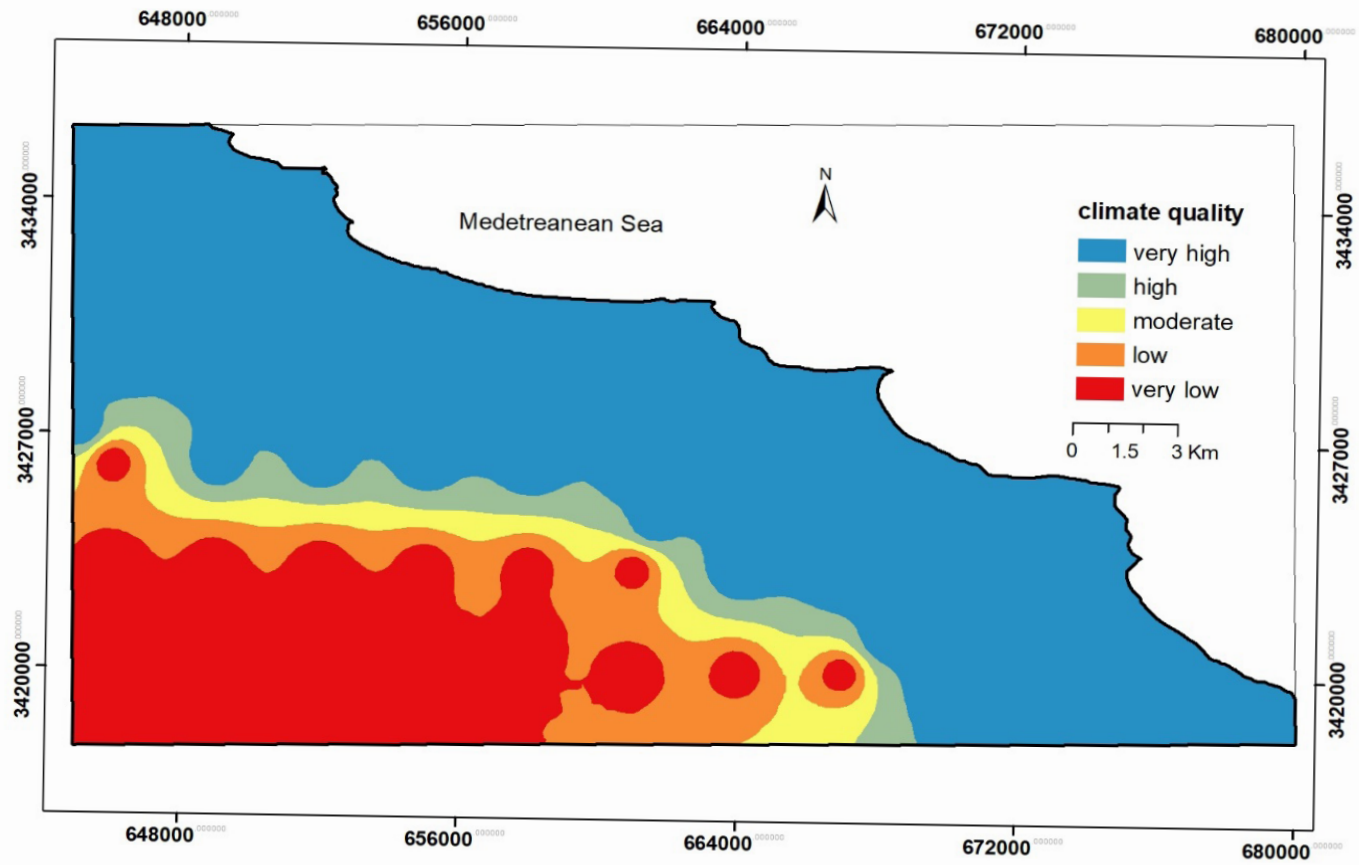

Fig. 3. Climate indicator quality map of Sidi-Abdel Rahman area

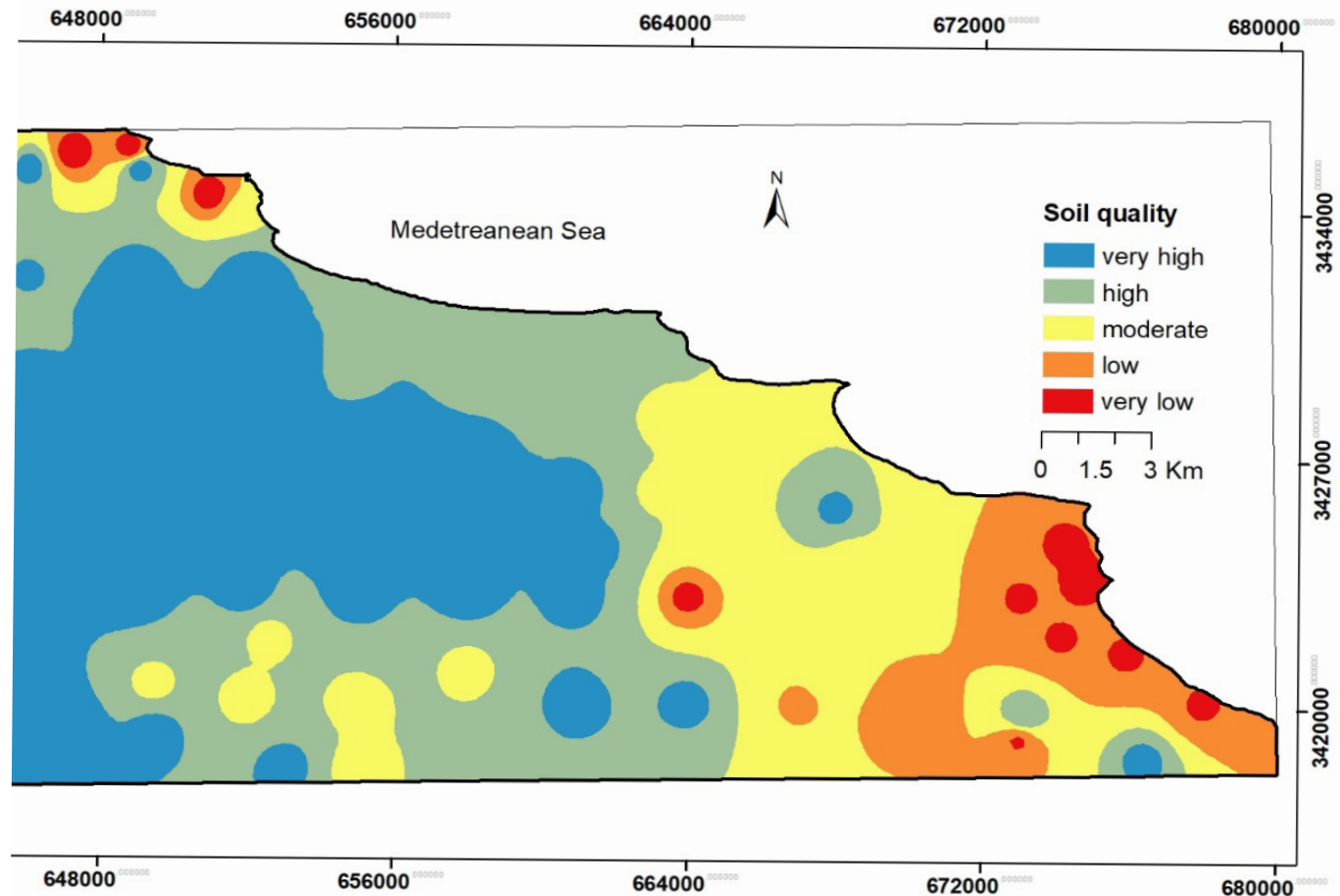

Fig. 4. Soil indicator quality map of Sidi-Abdel Rahman area 


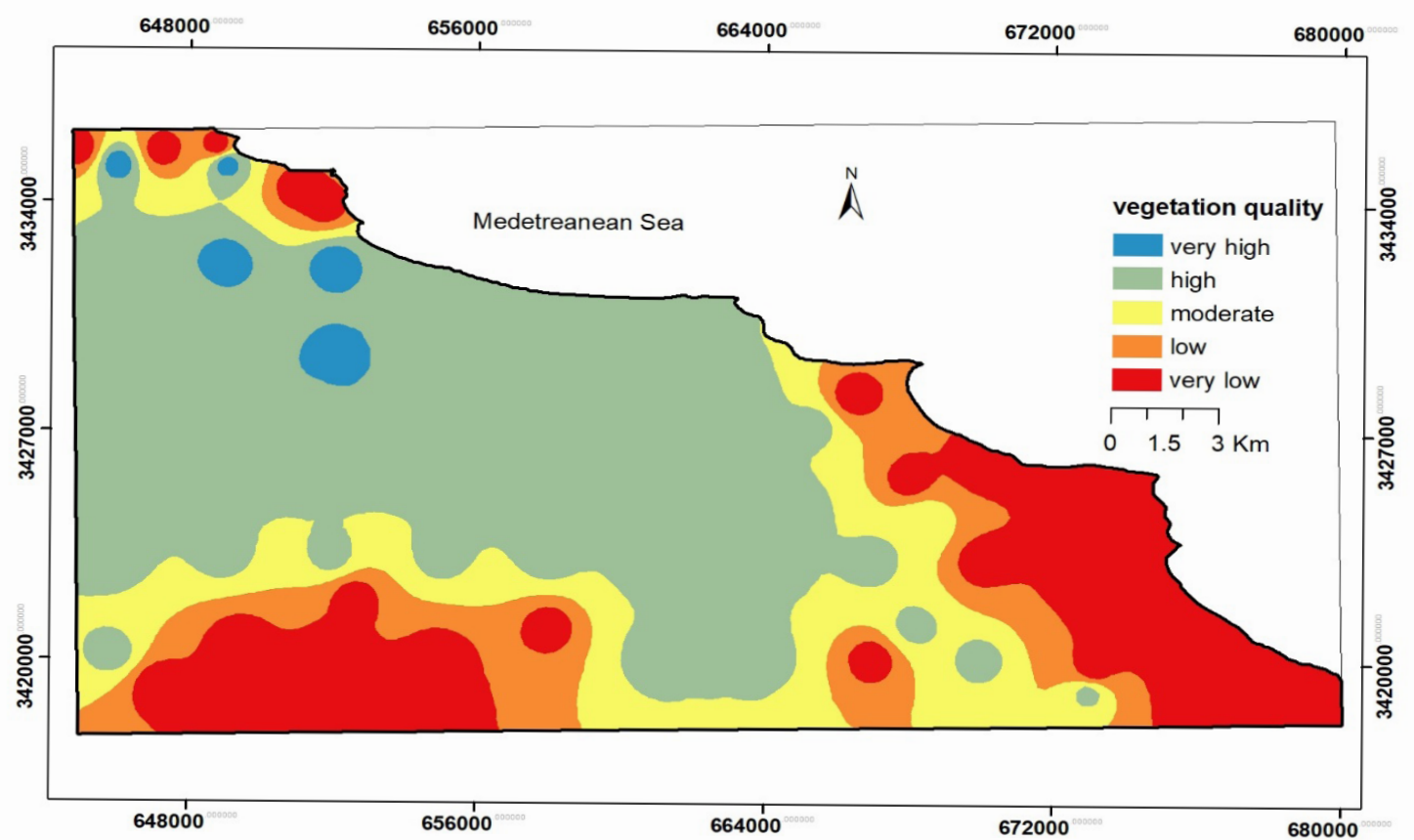

Fig. 5. Vegetation indicator quality map of Sidi-Abdel Rahman area

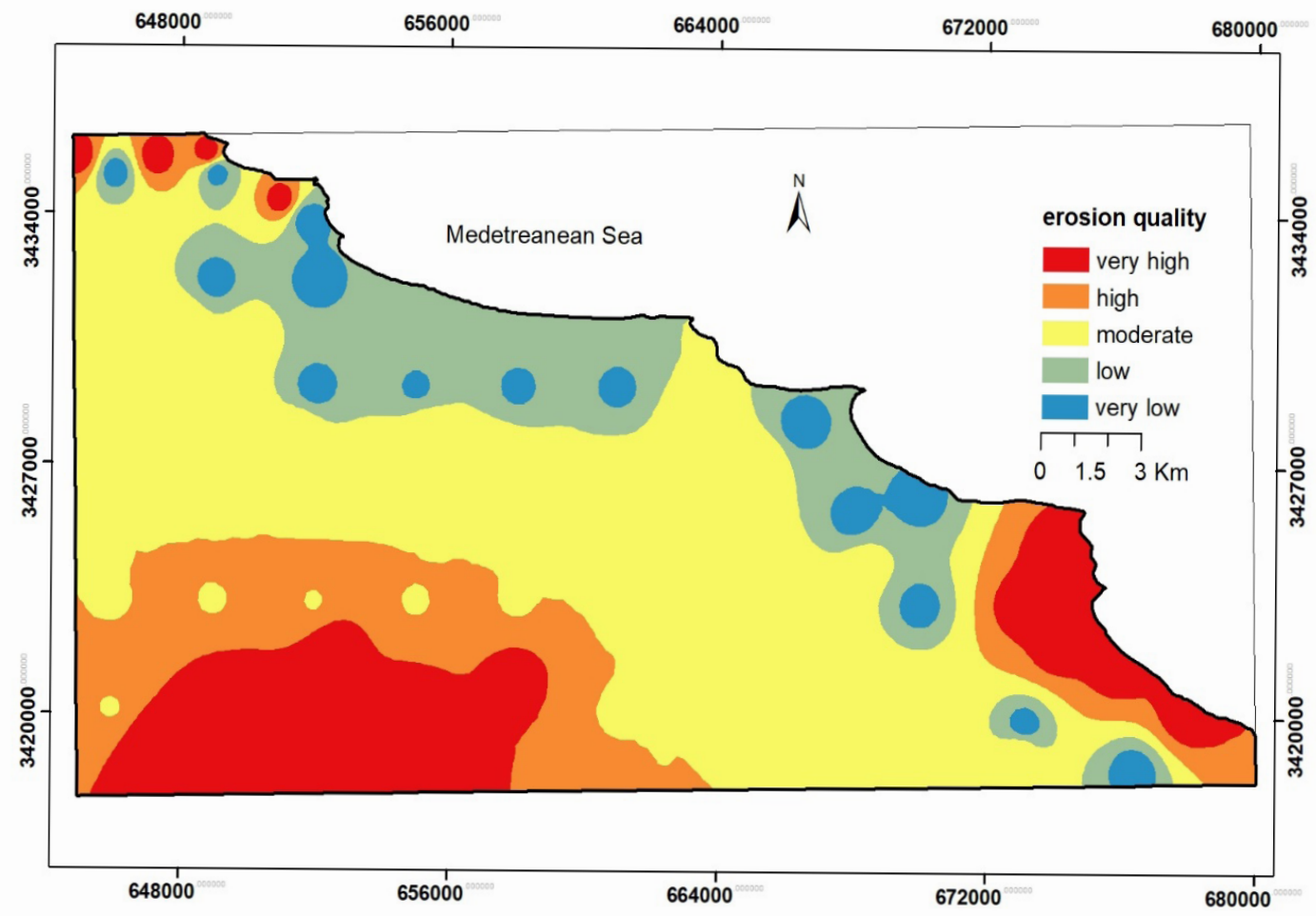

Fig. 6. Erosion indicator quality map of Sidi-Abdel Rahman area 


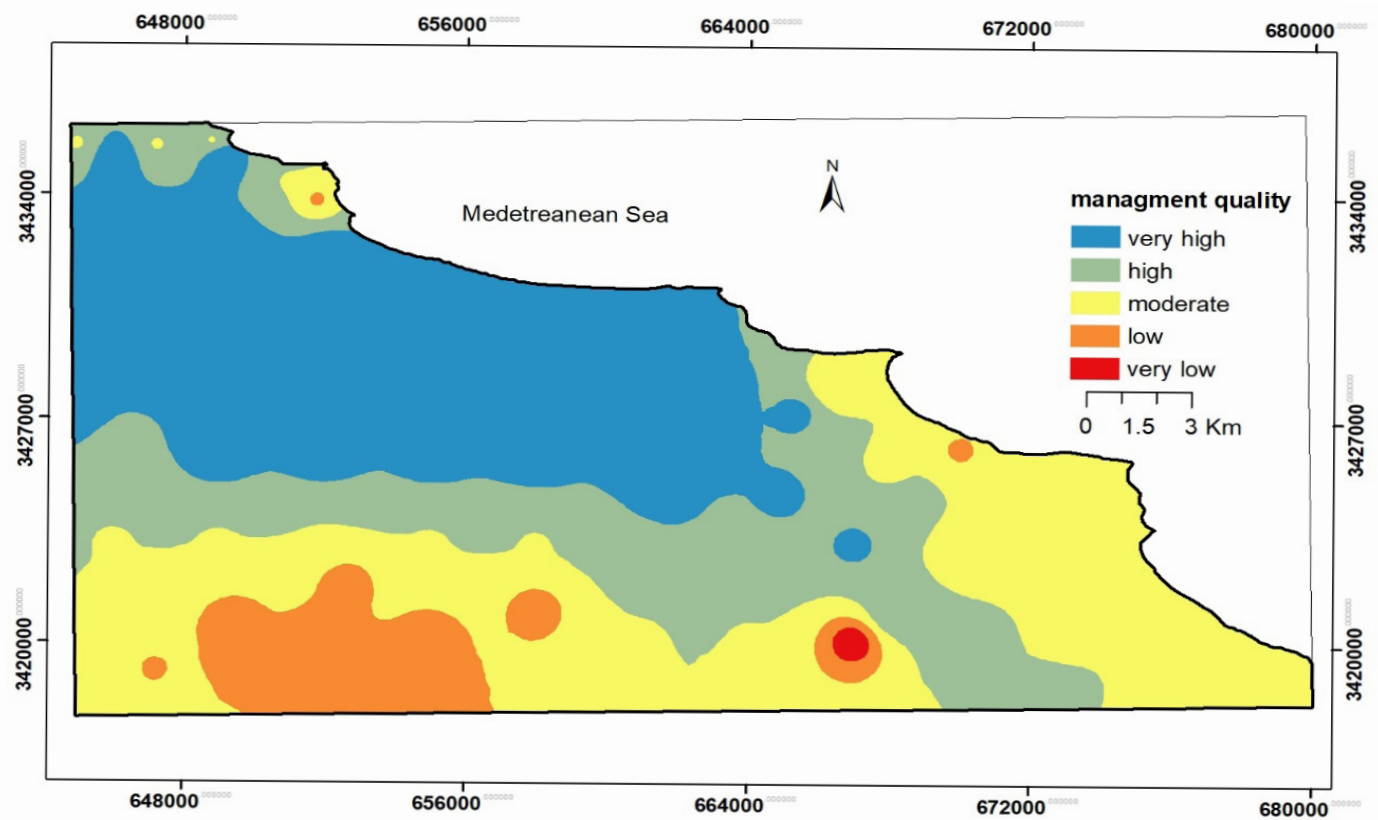

Fig. 7. Management indicator quality map of Sidi-Abdel Rahman area

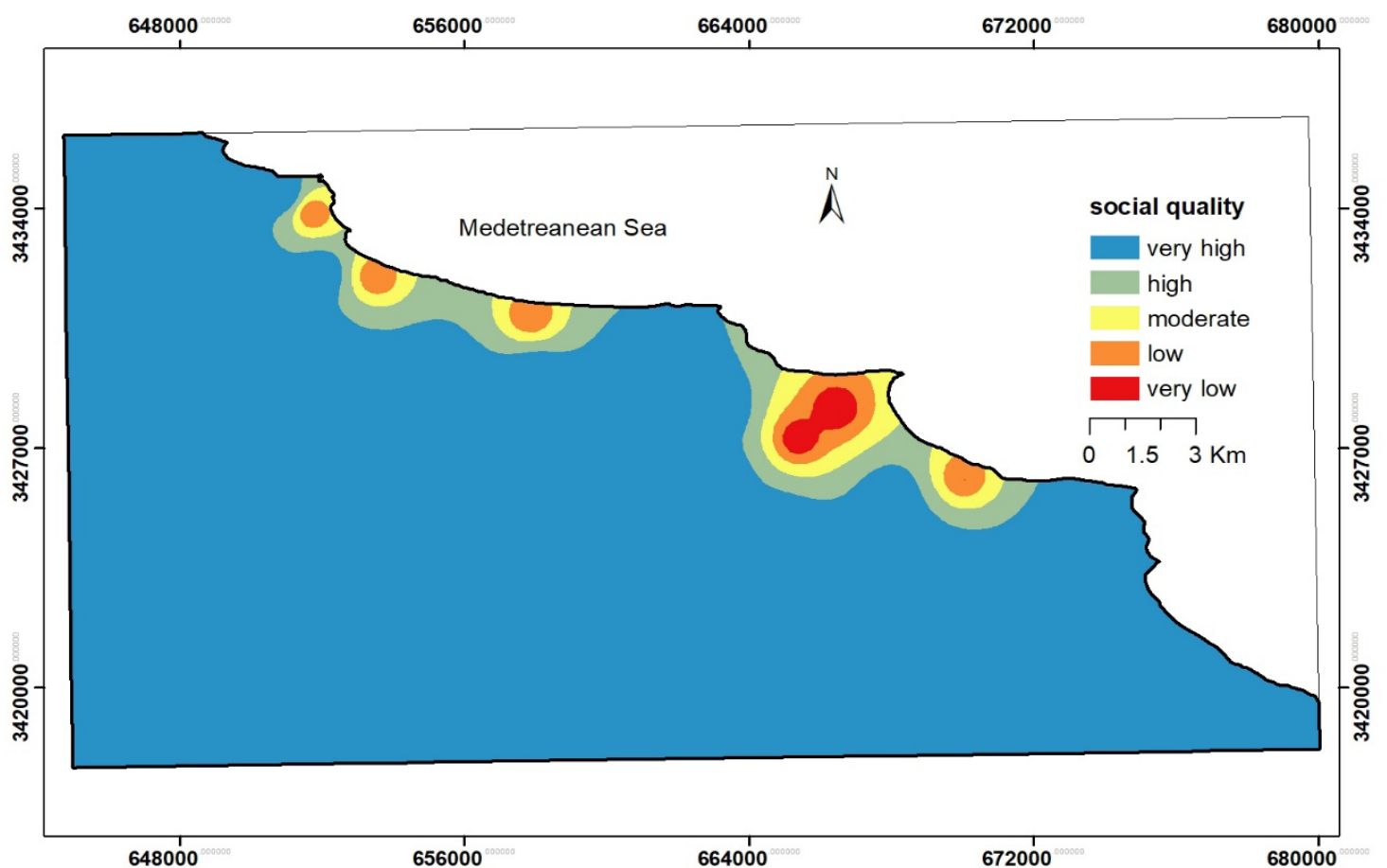

Fig. 8. Social indicator quality map of Sidi-Abdel Rahman area 


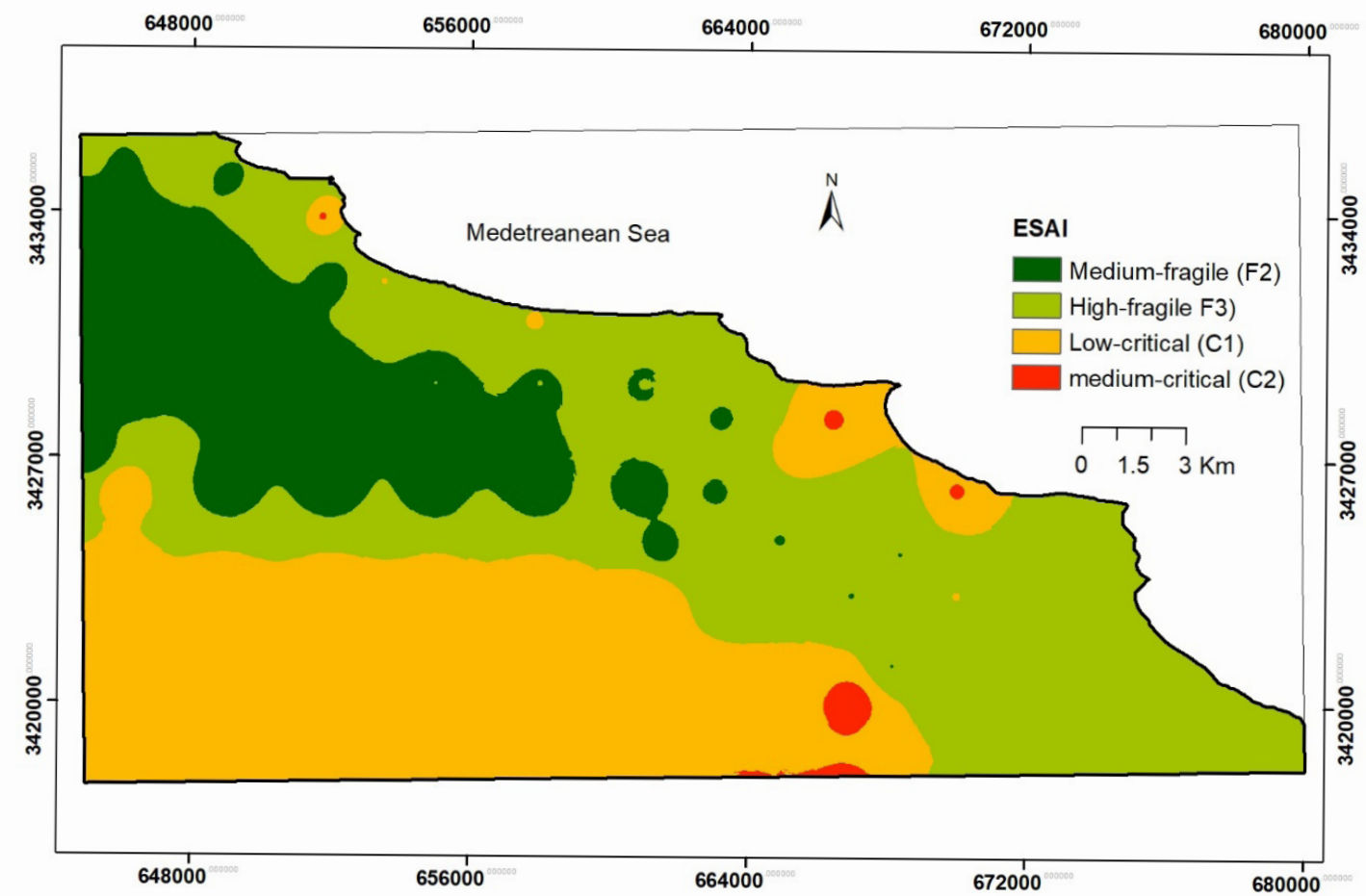

Fig. 9. Mapping of desertification sensitivity in Sidi Abdel-Rahman area

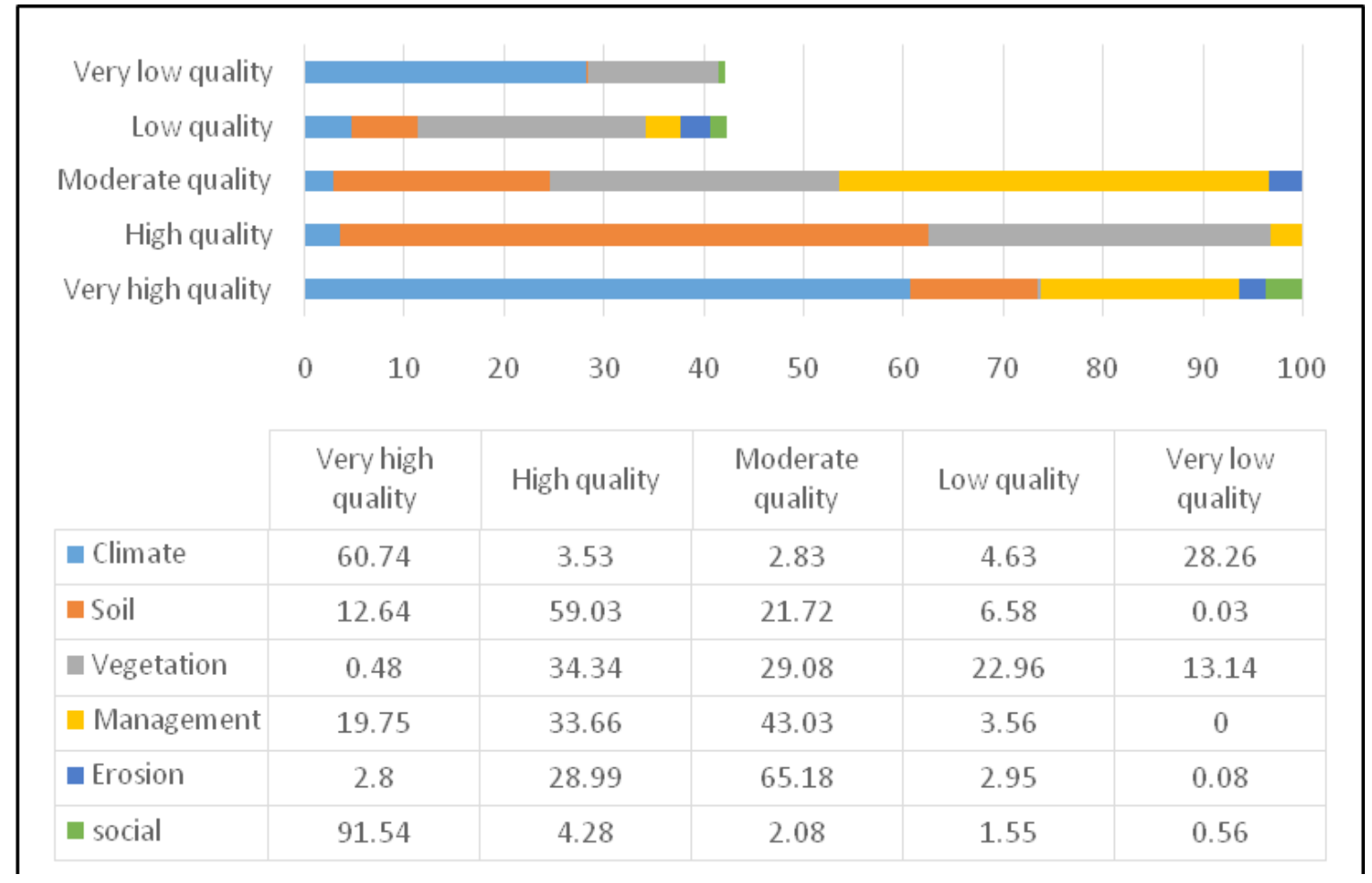

Fig. 10. Desertification qualities distribution in Sidi-Abdel Rahman area (\%) 
TABLE 2. Summarized results of sensitive area to desertification

\begin{tabular}{lccc}
\hline \multirow{2}{*}{ Desertification } & \multicolumn{3}{c}{ Area } \\
\cline { 2 - 4 } & $\mathrm{Km}^{2}$ & Feddan & 20.62 \\
\hline Medium-fragile & 85.10 & 20262.06 & 43.36 \\
High-fragile & 178.93 & 42603.17 & 35.35 \\
Low-critical & 145.86 & 34729.38 & 0.66 \\
Medium-critical & 2.74 & 651.33 & \\
\hline
\end{tabular}

combat desertification in Sidi Abdel-Rahman area. Based on the developed desertification map, almost $79.37 \%$ of study area was sensitive to and affected by desertification owed to low vegetation cover, soil quality, mismanagement, climate condition, and wind and water erosion. The soil vegetation cover should be increased by less water demanding plant species, and also establishing a water erosion control. The developed ESA model can assess the extent, intensity and severity of desertification process in the target area. However, there is scope for minor improvements whenever more recent data is available.

\section{References}

Adger, W. N., Benjaminsen, T. A., Brown, K. and Svarstad, H. (Ed.) Advancing a Political Ecology of Global Environmental Discourse. (2000) Centre of Social and Economic Research on the Global Environment, University of East Anglia, London.

Ali, R.R. and El Baroudy, A.A. (2008) Use of GIS in mapping the environmental sensitivity to desertification in Wadi El Natrun depression, Egypt. Australian Journal of Basic and Applied Sciences 2 (1), 157-164.

Archer, E. R. M. (2004) Beyond the "climate versus grazing" impasse: using remote sensing to investigate the effects of grazing system choice on vegetation cover in the eastern Karoo. J. Arid Environ. 57,381-408.

AUA (Agricultural University of Athens). (2008) Manual for describing land degradation indicators. DESIRE-WB2, (41 pp.).

Babaev, A. G. (1985) Methodological Principals of Desertification Processes Assessment and Mapping. Turkmenistan: Desert Research Institute.

Bahreini, F. and Pahlavanravi, A. (2013) Assess and mapping the environmental sensitivity to desertification (a case study in Boushehr Province, Southwest Iran). Int. J. Agric. Crop Sci. 5 (18), 2172-2183.
Basso, F., Bove, E., Dumontet, A., Ferrara, A., Pisante, M., Quaranta, G. and Taberner, M. (2000) Evaluating environmental sensitivity at the basin scale through the use of geographic information systems and remotely sensed data: an example covering the Agri basin (Southern Italy). Catena; 40, 19-35.

Bouabid, R., Rouchdi, M., Badraoui, M., Diab, A. and Louafi, S. (2010) Assessment of land desertification based on the MEDALUS approach and elaboration of an action plan: the case study of the Souss River Basin, Morocco. Land Degradation and Desertification: Assessment, Mitigation 131 and Remediation. Springer Science + Business Media B.V. (131-145 pp.).

Brandt, J. (2005) Desertification information system to support National Action Pro-grammes in the Mediterranean (DISMED). DIS4ME, Desertification Indicator System for Mediterranean Europe. www.unibas.it/desertnet/dis4me/using dis 4 me/dismed.htm

Calanca, P., Smith, P., Holzkämper, A. and Ammann, C., (2011) L'évapotranspiration de reference et son application enagrométéorologie. Station de recherche AgroscopeReckenholz-Tänikon ART, 8046 Zurich. Rech. Agronomique Suisse. 2 (4), 176-183.

Collado, A. D., Chuvieco, E. and Camarasa, A. (2002) Satellite remote sensing analysis to monitor desertification processes in the crop-rangeland boundary of Argentina. J. Arid Environ. 52,121-133.

Coscarelli, R., Caloiero, T., MinervinoI., and Sorriso, M. (2016) Sensitivity to desertification of a high productivity area in Southern Italy, Journal of Maps, 12 (3), 573-581.

ESRI. (2013) ArcGIS Desktop: Release 10.2. Redlands, CA, USA.

FAO and UNEP (1984) Provisional Methodology for Assessment and Mapping of Desertification, FAO, Rome, $84 \mathrm{pp}$. 
Ferrara, A., Bellotti, A., Faretta, S., Mancino, G. and Taberner, M. (1999) "Identification and assessment of Environmentally Sensitive Areas by Remote Sensing” MEDALUS III 2.6.2. - OU Final Report. King's College, London. Volume, 2, 397-429.

Gad, A. and Lotfy, I. (2006) Use of remote sensing and GIS in mapping the environmental sensitivity areas for desertification of Egyptian territory. The 2nd International Conf. on Water Resources \& Arid Environment, 26-29 November 2006. King Saud University.

Gad, A. and Lotfy, I.(2008) Use of remote sensing and GIS in mapping the environmental sensitivity areas for desertification of Egyptian territory. E. Earth Discuss. 3, 41-85.

Gad, A. and Shalaby, A. (2010) Assessment and mapping of desertification sensitivity using remote sensing and GIS. Case study: inland Sinai and eastern desert wadies. US-Egypt Workshop on Space Technology and Geo-information for Sustainable Development, Cairo, Egypt 14-17 June 2010, p. 6.

Herrmann S.M. and Hutchinson, C.F. (2005) The changing contexts of the desertification debate. $J$ Arid Environ. 63, 538-555

Honardoust, F., Ownegh, M. amd Sheikh, V. (2011) Assessing desertification sensitivity in the northern part of Gorgan Plain, southeast of the Caspian Sea, Iran. Res. J. Environ. Sci. (ISSN: 1819-3412) 5 (3), 205-220.

Jabbar, M. T. and Chen, X. L. (2006) Land degradation assessment with the aid of geoinformation techniques. Earth Surface Processes Landforms; 3, 777-784.

Kosmas, C., Kirkby, M. and Geeson, N., (1999) The MEDALUS project: Mediterranean desertification and land use. Manual on Key Indicators of Desertification and Mapping Environmentally Sensitive Areas to Desertification European Commission, Project ENV4 CT 950119 (EUR 18882).

Kosmas, C., Tsara, M., Moustakas, N. and Karavitis, C. (2003) Dentification of indicators for desertification. Ann. Arid Zones, 42, 393-416.

Lahlaoi, H., Rhinane, H., Hilali, A., Lahssini, S. and Moukrim, S. (2017) Desertification Assessment Using MEDALUS Model in Watershed Oued El Maleh, Morocco. Geosciences. 2017; 7(3), 50.

Lavado, C. J. F., Schnabel, S., Mezo Gutierrez, A. G. and Pulido, F. M. (2009) Mapping sensitivity to land degradation, Extremadura, south-west Spain. Land Degrad. Dev. 20,129-144.

Le Bissonnais, Y. (1996) Aggregate stability and assessment of crustability and erodibility: 1 . Theory and methodology. Eur. J. Soil Sci. 47, 425-437

Luca, S. and Sofia, B. (2011) Land sensitivity to desertification across Italy: Past, present, and future. Appl.Geogr. 31, 223-231

Mohamed, E.S. (2013) Spatial Assessment of Desertification in North Sinai Using Modified MEDLAUS Model. Arabian J. Geosciences.

Montanarella, L. (2007) Trends in land degradation in Europe. In: Sivakumar MV, N'diangui N (Ed.) Climate and Land Degradation. Springer, Berlin.10.1007/978-3-540-72438-4_5

Nicholson, S.E., Tucker, C.J. and Ba. M.B. (1998) Desertification, Drought and Surface Vegetation: an example from the West African Sahel. Bulletin of the American Meteorological Society, 79(5), 815-829.

Parvari, S.H., Pahlavanravi, A., Nia, A.R.M. and Dehvari, A. (2011) Application of methodology for mapping environmentally sensitive areas (ESAs) to desertification in dry bed of Hamoun Wetland (Iran). Int. J. Nat. Resour. Mar. Sci. 1 (1), 65-80

Prăvălie R., Săvulescu, I., Patriche, C., Dumitraşcu, M. and Bandoc, G. (2017) Spatial assessment of land degradation sensitive areas in south western Romania using modified MEDALUS method. Catena. 153,114-130.

Reynolds, J. F. and Stafford Smith, D. M. (2002) Global Desertification: Do Humans Cause Deserts? Vol. 88, Dahlem University Press.

Rubio J.L. (1995) Desertification: evolution of a concept. In: Fantechi R, Peter D, Balabanis P, Rubio JL (Ed.) EUR 15415 desertification in a European context: physical and socio-economic aspects. Office for Official Publications of the European Communities, Brussels, pp 5-13

Runnstrom, M. C. (2003) Rangeland development of the Mu Us sandy land in semi-arid China: an analysis using Landsat and NOAA remote sensing data. Land Degradat. Dev. 14, 189-202.

Said, R. (1990) The Geology of Egypt, A. A. Balkema / Rotterdam /Brookfield.

Sepehr, A., Hassanli, A. M., Ekhtesasi, M. R. and 
Jamali, J. B. (2007) Quantitative assessment ofdesertification in south of Iran using MEDALUS method. Environ. Monitor. Assess. 134, 243-254.

Tavares J., Baptista I., Ferreira A., Amiotte-Suchet P., Querido A., Coelho, C.,Gomes S., Amoros R., Bentub J., Varela L., Reis A. (2015) Assessment and mapping desertification sensitivity in an insular Sahelianmountain region. Case study of Ribeira Seca Watershed, Cape Verde. Catena. 128, 214223.

Thomas, D. S. G. (1997) Science and desertification debate. J. Arid Environ. 37, 599-608.

Thornes J.B. (1995) Mediterranean desertification and the vegetation cover. In: Fantechi R., Peter D., Balabanis P., Rubio J.L. (Ed.) EUR 15415 desertification in a European context: physical and socio-economic aspects. Office for Official Publications of the European Communities, Brussels, pp 169-194

Tucker, C.J., Dregne, H.E. and Newcomb, W,W, (1991) Expansion and Contraction of the Sahara Desert from 1980 to 1990. Science, 253: 299-301. n 18882. pp: 31-47 ISBN 92-828-6349-2.

UNCCD (United Nations Convention for Combating Desertification) (2000) Assessment of the Status of Land Degradation in Arid, Semi-arid and Dry Sub-humid Areas. United Nations Convention to Combat Desertification, Bonn Germany.

UNEP (1992) United Nations Conference on Environment \& Development, Agenda 21, Chapter
12, Adopted at the Rio Conference June, 1992. UN New York

USDA (2010) Keys To Soil Taxonomy, 11th ed. United State Department of Agriculture, Natural Resources Conservation Service (NRCS).

Wang, X., Chen, H. F., Dong, Z. and Xia, D. (2005) Evolution of the southern $\mathrm{Mu}$ Us desert in north China over the past 50 years: an analysis using proxies of human activity and climate parameters. Land Degradat. Dev. 16, 351-366.

Yang, X., Zhang, K., Jia, B. and Ci, L. (2005) Desertification assessment in China: an overview. J. Arid Environ. 63, 517-531

Zheng, Y. R., Xie, Z. X., Robert, C., Jiang, L. H. and Shimizu, H. (2006) Did climate drive ecosystem change and induce desertification in Otindag sandy land, China over the past 40 years? J. Arid Environ. 64, 523-541.

Zambon I., Colantoni A., Carlucci M., Morrow N., Sateriano, A. and Salvati L. (2017) Land quality, sustainable development and environmental degradationin agricultural districts: A computational approach based onentropy indexes. Environmental Impact Assessment Review, 64, 37-46.

(Received: 12 / 9 / 2017 ; accepted: 15 / $10 / 2017)$ 